
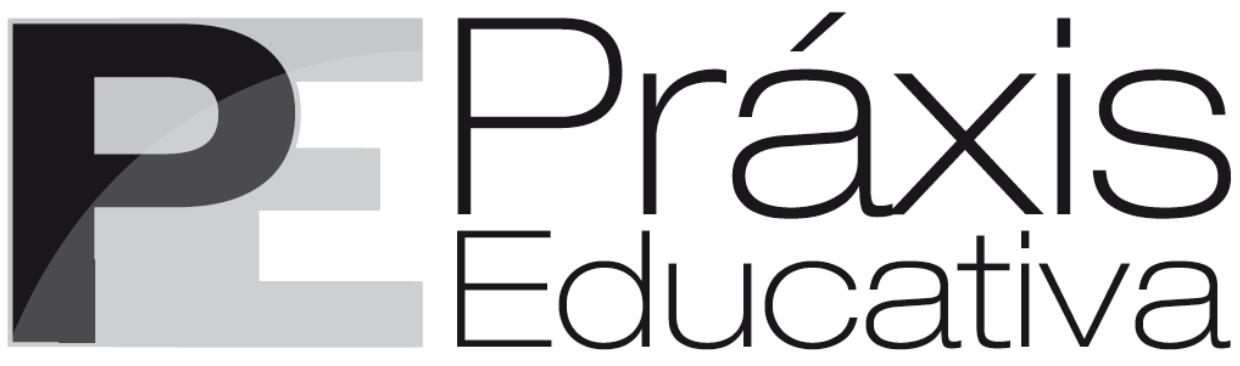

ISSN 1809-4309 (Versão online)

DOI: 10.5212/PraxEduc.v.12i2.0018

\title{
Trabalho e trabalhadores no Terceiro Anel na Região Metropolitana de Curitiba: parcialização, baixa qualificação e desafios educacionais
}

\section{Work and workers in the Third Ring in the Metropolitan Region of Curitiba: partialization, low qualification and educational challenges}

\author{
El trabajo y los trabajadores en el tercer anillo en la Región Metropolitana \\ de Curitiba: parcialidad, bajo nivel de capacitación y desafíos educativos
}

Patrícia Correia de Paula Marcoccia* Maria de Fátima Rodrigues Pereira*

\begin{abstract}
Resumo: Este artigo apresenta resultados de uma pesquisa sobre as condições de trabalho dos trabalhadores do campo no Terceiro Anel, na Região Metropolitana de Curitiba (RMC), e estabelece relação entre os meios de produção da vida e a apropriação dos trabalhadores familiares quanto ao acesso à educação escolar. O método de pesquisa adotado é o materialismo histórico dialético que se orienta pela teoria social de Marx, a qual considera, em primeiro lugar, a produção material socialmente determinada (MARX, 2008). Neste texto, consideram-se as relações entre as condições de trabalho, a educação e a apropriação dos bens e a produção social dos homens no tempo histórico atual. Por meio do método enunciado, analisaram-se documentos disponibilizados publicamente no Sistema Público de Emprego e Renda (ISPER) e no Instituto Paranaense de Desenvolvimento Econômico e Social (IPARDES), entre outros. Esses documentos possibilitaram conhecer aspectos das condições de trabalho dos trabalhadores do campo no Terceiro Anel, na RMC, e apontar que o trabalho assalariado mantém relações de parcialização e desqualificação, e os meios de produção da vida e de apropriação quanto ao acesso à educação escolar dos trabalhadores familiares corresponde a uma exclusão da existência, pois suas condições objetivas e subjetivas carregam as marcas da submissão do trabalho ao capital.
\end{abstract}

Palavras-chave: Trabalho. Trabalhadores do campo. Educação.

Abstract: This paper presents results of a research on working conditions of workers in the Third Ring in the Metropolitan Region of Curitiba (MRC) and establishes a relationship between the means of production of life and the appropriation of family workers regarding the access to school education. The method of research adopted is the dialectical historical materialism that is guided by Marx's social theory, which considers, in the first place, the socially determined material production (MARX, 2008). In this text, we consider the relations between working conditions, education and the appropriation of goods and the social production of men in the present historical time. Through the method enunciated, we analyzed documents publicly available in the Public System of Employment and Income (ISPER) and the Institute of Economic and Social Development of Paraná (IPARDES), among others. These documents made it

\footnotetext{
* Professora da Universidade Estadual de Ponta Grossa (UEPG). E-mail: <pa.tyleo12@gmail.com>.

** Professora da Universidade Tuiuti do Paraná (UTP). E-mail: <maria.pereira@utp.br>.
} 
possible to know aspects of the working conditions of the workers in the Third Ring in the MRC and pointed out that wage labor has relations of partialization and disqualification, and the means of production of life and appropriation regarding the access to school education of family workers corresponds to an exclusion of existence, because its objective and subjective conditions carry the marks of submission of labor to capital.

Keywords: Work. Field workers. Education.

Resumen: En este artículo se presentan los resultados de una investigación sobre las condiciones de trabajo de los trabajadores de campo en el Tercer Anillo, en la Región Metropolitana de Curitiba (RMC), y se establece la relación entre los medios de producción de la vida y la apropiación de los trabajadores familiares respecto al acceso a la educación. El método de investigación adoptado es el materialismo histórico dialéctico, guiado por la teoría social de Marx, que considera en primer lugar la producción de materiales socialmente determinada (MARX, 2008). En este texto, se considera la relación entre las condiciones de trabajo, la educación y la propiedad de bienes y la producción social de los hombres en el momento histórico actual. A través del método mencionado, se analizaron los documentos disponibles al público en el Sistema Público de Empleo e Ingresos (ISPER) y Instituto Paranaense para el Desarrollo Económico y Social de (IPARDES), entre otros. Estos documentos han permitido conocer aspectos de las condiciones de trabajo de los trabajadores de campo en el Tercer Anillo, en la MRC, y señalar que el trabajo asalariado tiene relaciones de parcialidad y la descalificación y los medios de producción de la vida y de apropiación en el acceso a la educación escolar de los trabajadores familiares, que corresponde a una exclusión de la existencia porque sus condiciones objetivas y subjetivas llevan las marcas de la sumisión del trabajo al capital.

Palabras clave: Trabajo. Trabajadores de campo. Educación.

\section{Introdução}

No Brasil, a classe trabalhadora, especialmente com a reestruturação produtiva, promovida pelas empresas a partir do início dos anos 1990, nos governos Fernando Collor de Melo e Fernando Henrique Cardoso, e as políticas neoliberais que lhe corresponderam, apresenta-se de forma heterogênea, polissêmica e multifacetada (ANTUNES, 2011), com implicações na sua existência.

As modificações da classe trabalhadora, segundo Braga (2016, p. 58), foram intensificadas com o desmonte das formas de "[...] solidariedade fordista promovido pela empresa neoliberal com o avanço do padrão de consumo pós-fordista estimulado pela globalização econômica, [a qual] impulsionou um avanço sem precedentes da individualização do comportamento da classe trabalhadora".

Por sua vez, as relações do trabalho com o capital, por meio das empresas, promoveram um acelerado movimento de reestruturação produtiva que fragmentou, flexibilizou, intensificou e precarizou o trabalho. O efeito desse movimento foi integrar diferentes formas de contratação, promovendo o trabalho desqualificado, barato, um traço salientado em virtude da periferia do Brasil em relação aos países centrais do capitalismo. Junta-se à condição do trabalho temporário, subcontratado, o elevado número de acidentes e a alta taxa de rotatividade.

No que tange à alta rotatividade, o Departamento Intersindical de Estatística e Estudos Socioeconômicos (DIEESE, 2014) constatou que, em 2013, ela chegou a 63,7\%, confirmando que o emprego que mais se expressa no Brasil é o de curta duração, que se caracteriza pela flexibilidade contratual de trabalho. Outro dado relevante é que houve crescimento de participação da faixa etária entre 50 e 64 anos tanto no caso de ativos como de desligamento. Além disso, houve redução da faixa etária entre 18 a 24 anos.

Práxis Educativa, Ponta Grossa, v. 12, n. 2, p. 595-616, maio/ago. 2017 Disponível em: <http://www.revistas2.uepg.br/index.php/praxiseducativa> 
Nesse cenário, Ruy Braga destaca que:

[...] aos aumentos do salário mínimo acima da inflação seguiu-se um endurecimento nas condições de consumo da força de trabalho: nos anos 2000, a taxa de rotatividade do trabalho do país aumentou cerca de 10\% (de 33\%, em 1999), para 36\% em 2009. Para aqueles que ganham entre 0,5 e 1,5 salário mínimo, a taxa de rotatividade foi de $86 \%$ em 2009, ou seja, um aumento de 42\% em comparação com 1999 [...]. (BRAGA, 2016, p. 61).

A educação, nesse contexto, está ancorada nos princípios neoliberais e responde pela aprendizagem flexível que se configura pelo "[...] regime de acumulação flexível, cimentado pela ideologia pós-moderna” (KUENZER, 2016, p. 2), cuja lógica assenta-se no discurso homogêneo de que se deve aprender ao longo da vida. Disso resulta uma força de trabalho que se adapte "naturalmente" e persiga constantemente as diversas demandas do mercado flexível em cada tempo histórico. A finalidade da aprendizagem flexível é formar trabalhadores que assegurem a lucratividade do capital. Trata-se, afinal, de formação do trabalho barato e massificado para a produção e a reprodução do capital.

A lógica da aprendizagem flexível expressa-se nos dados apresentados pelo DIEESE (2014), o qual constatou maior desligamento dos trabalhadores que apresentavam menor escolaridade, ou seja, Ensino Fundamental incompleto e completo. Por outro lado, houve uma "[...] tendência de aumento de escolaridade dos trabalhadores do segmento celetista" (DIEESE, 2014, p. 6-7). Esse dado corrobora com os estudos de Braga (2013, p. 150), o qual menciona que há uma mudança no perfil da classe trabalhadora, ou seja, há mais "[...] mulheres trabalhando e a escolaridade aumentou, ao ponto de o diploma de Ensino Médio ter se transformado em um critério mínimo para a entrada no mercado de trabalho".

Por sua vez, essa relação é atravessada por contradições que se entrelaçam continuamente, pois o capital necessita ininterruptamente da extração da força de trabalho flexibilizada mediante qualificações diversificadas, as quais impõem a distribuição desigual do conhecimento, os tais percursos formativos. Além disso, o capital também é forçado a atender e reconhecer, na correlação de forças, as demandas dos trabalhadores quanto à reprodução de suas vidas, o que não se faz sem lutas por acesso à educação, nomeadamente ao ensino da arte, da ciência, da filosofia.

A questão que se coloca é que o regime de acumulação flexível para a maioria dos trabalhadores se expressa "[...] em atividades laborais de natureza simples e desqualificada", sendo "[...] precariamente qualificados por processos rápidos de treinamento, com apoio nas novas tecnologias e com princípios da aprendizagem flexível (KUENZER, 2016, p. 5). Um dilema possível de ser transposto pelas lutas sociais.

Embora a situação dos trabalhadores sob os ditames do capital tenha essas características, considera-se que o trabalho no campo manifesta em extremo essas condições, sobretudo pela expansão do trabalho parcializado, terceirizado, subcontratado e temporário. Também manifesta a essa heterogeneidade referida, uma vez que não se restringe aos trabalhadores assalariados que vendem a sua força de trabalho, há os agricultores familiares ${ }^{1}$ que não estão submetidos

\footnotetext{
1 A expressão agricultura familiar/camponesa para alguns intelectuais é vista sob a perspectiva da integração ao capital, que se afeiçoa à dinâmica empresarial e à profissionalização (ABRAMOVAY, 2012). Ricardo Abramovay, no seu livro Paradigmas do capitalismo agrário em questão (2012), defende que a situação do campo brasileiro é um problema conjuntural e, para avançar, é necessário integrar a lógica da agricultura familiar nas estruturas nacionais de mercado. Essa questão embasa-se na estrutura social da agricultura nos países capitalistas avançados. Para outros intelectuais, o termo camponês refere-se àquele que não se integra a essa lógica, porque se coloca na posição de resistência a essa integração (FERNANDES, 2008). Compreender a expressão agricultor familiar como sinônimo de camponês ou não
}

Práxis Educativa, Ponta Grossa, v. 12, n. 2, p. 595-616, maio/ago. 2017 Disponível em: <http://www.revistas2.uepg.br/index.php/praxiseducativa> 
Trabalho e trabalhadores no Terceiro Anel na Região Metropolitana de Curitiba: parcialização...

diretamente à extração de mais valia. Uns e outros encontram-se em situação de desapropriados, seja da propriedade da terra e dos instrumentos de trabalho, no caso dos trabalhadores assalariados, seja do trabalhador familiar que não consegue competir com o agronegócio e sua moderna tecnociência. Uns e outros expropriados ${ }^{2}$ em virtude da maneira como os meios de produção da vida e a educação foram distribuídos e apropriados nas relações sociais.

Dessa compreensão é que resulta o objetivo deste artigo que é apresentar as condições de trabalho dos trabalhadores do campo no Terceiro Anel, na RMC, e estabelecer relação entre os meios de produção da vida e a apropriação dos trabalhadores familiares quanto ao acesso à educação escolar.

Os procedimentos utilizados neste estudo são a pesquisa bibliográfica, decorrente de pesquisas anteriores em documentos impressos e pesquisa documental, que possibilitou a coleta e a análise dos documentos a respeito do trabalho no Terceiro Anel, na RMC, disponibilizados no Sistema Público de Emprego e Renda (ISPER), na Relação Anual de Informações Sociais (RAIS), no Ministério do Trabalho e Emprego, no Instituto Paranaense de Desenvolvimento Econômico e Social (IPARDES) e na Empresa de Assistência Técnica e Extensão Rural (EMATER).

O método ${ }^{3}$ eleito sustenta-se em Marx, que considera,

[...] em primeiro lugar, a produção material. Como os indivíduos produzem em sociedade, a produção de indivíduos, socialmente determinada, é, naturalmente, o ponto de partida. O caçador ou o pescador particular e isolado, pelo qual começam Smith e Ricardo, pertencem às triviais imaginações do século 18. São robionsonadas [...]. (MARX, 2008, p. 237-238)

Nesse sentido, o método implica em apontar que toda a produção é socialmente determinada e de modo nenhum está ligada a homens independentes por natureza. Este estudo estabelece as relações entre as condições de trabalho do Terceiro Anel, na RMC, a educação, a apropriação dos bens e a produção social de homens na atual conjuntura histórica da reestruturação produtiva. Por meio dessas relações mencionadas, é que foram analisados os referidos documentos, os quais possibilitaram conhecer as condições do trabalho dos trabalhadores do campo no Terceiro Anel, na RMC, e apontar que há precarização do trabalho desses trabalhadores, bem como do acesso à escolaridade e ao conhecimento, pois suas

se refere à abordagem teórica e ao método utilizado. Entretanto, nesta pesquisa, emprega-se o termo trabalhador, pois parte de uma concepção mais ampla de trabalho que considera que o agricultor familiar, embora esteja integrado ao grande capital, não se apropria de toda renda fundiária. Nesse sentido, tanto o agricultor familiar quanto o camponês estão sob processos de trabalho subordinado ao modo de produção capitalista que impõe formas de trabalho de produção destrutiva e tem degradado a vida humana.

${ }^{2}$ No capítulo XXIV de $O$ Capital, intitulado $A$ chamada acumulação primitiva, Marx apresenta e analisa como se deu a expropriação dos camponeses na Inglaterra e sua passagem da violência individual à sua institucionalização por meio da lei. Diz o autor: "Conforme vimos, a violência que se assenhoreia das terras, pela transformação das lavouras em pastagens, começa no fim do século XV e prossegue no século XVI. Mas, então, o processo se efetiva [...]. No século XVIII, consiste em ter tornado a própria lei em veículo do roubo das terras pertencentes ao povo, embora os grandes arrendatários empregassem simultaneamente e independentemente seus métodos particulares. O roubo assume a forma parlamentar [...], ou melhor, os decretos com que os senhores das terras se presenteiam com os bens que pertencem ao povo, tornando-os sua propriedade particular, decretos de expropriação do povo" (MARX, 2009, p. 838).

3 Os apontamentos sobre o método que ora se fazem são da Introdução à Contribuição à Crítica da Economia Política, texto que permaneceu inédito quando da vida de Marx e que faz parte dos textos produzidos entre 1857 e 1858. Marx está, tudo indica, relendo Hegel e, já na maturidade da sua produção, o método da economia política. É central nesse manuscrito o conceito de produção: produção em si, produção e outros elementos, produção e outras esferas da vida; e de visão de totalidade: produção, distribuição, troca e apropriação. Isso é relevante para as análises desenvolvidas neste texto.

Práxis Educativa, Ponta Grossa, v. 12, n. 2, p. 595-616, maio/ago. 2017 Disponível em: <http://www.revistas2.uepg.br/index.php/praxiseducativa> 
condições objetivas e subjetivas carregam as marcas da acumulação flexível que submete o trabalho ao capital. Essa forma de submissão é operada pelos processos de produção que se realizam de modo estranhado para o trabalhador, por meio do trabalho precarizado, do subemprego e do desemprego estrutural, conforme revela a empiria deste estudo.

Este texto está estruturado em três partes, a saber: A primeira apresenta uma breve caracterização da Região Metropolitana de Curitiba; a segunda caracteriza as condições do trabalhador do campo, com ênfase no trabalhador assalariado e no trabalhador familiar no Terceiro Anel, na RMC; a terceira aponta os desafios que se colocam à educação escolar. Por fim, as considerações finais.

\section{Caracterização da Região Metropolitana de Curitiba}

Atualmente, a RMC é constituída por 29 municípios, considerada a oitava mais populosa do país e a segunda maior em extensão, sendo sua área equivalente a 8\% do estado, e desta, 30\% representam o local de moradia da população urbana. Sua localização geográfica foi organizada de modo que estivesse próxima dos mais importantes mercados produtores e consumidores do Brasil, o que influenciou na formação de novas indústrias nos municípios.

Dados do Censo de 2010 (IBGE, 2010) revelam que a população total da RMC é de 3.223.836, estando 2.956.272 na área urbana e 267.564 na área rural. A população da área urbana está concentrada em Curitiba, juntamente aos municípios próximos à capital. A população rural reside nos municípios mais afastados, caracterizados por maior densidade demográfica e demandando grande deslocamento até os núcleos urbanos.

A RMC está dividida em três anéis, a saber: Primeiro Anel, Segundo Anel e Terceiro. O Primeiro Anel $^{4}$ é uma classificação utilizada para definir quais são os municípios que têm proximidade com a capital e possuem núcleos urbanos mais definidos devido ao seu grau de urbanização. Contudo, a utilização do termo Primeiro Anel não expressa consenso nos institutos de pesquisas do Brasil e nas produções acadêmicas, as quais entendem que há áreas de concentração da população (ACP) e áreas de menos concentração da população, representando as áreas de maior concentração grandes manchas urbanas de ocupação contínua, conforme aponta o IBGE (2008). O Segundo Anel $^{5}$ é constituído por municípios próximos à capital e municípios localizados em áreas rurais, e o Terceiro Anel ${ }^{6}$ é constituído por municípios rurais, sendo mais afastados da capital.

Os dados apresentados a seguir referem-se a uma revisitação nos dados do Instituto Brasileiro de Geografia e Estatística de 2010 e do Ministério da Saúde realizados por Guerra, Pochmann e Silva (2014), os quais criaram novos índices em três dimensões de análise: 1 - Vida digna, relacionado ao emprego, à pobreza e à desigualdade; 2 - Conhecimento, ligado à alfabetização e à escolaridade sobre a proporção de pessoas com 17 anos ou mais que concluíram o Ensino Médio; e 3 - Vulnerabilidade juvenil quanto ao risco de violência - trata-se do índice de exclusão social (GUERRA; POCHMANN; SILVA, 2014).

\footnotetext{
${ }^{4}$ Municípios que compõem o Primeiro Anel: Almirante Tamandaré, Araucária, Campina Grande do Sul, Campo Largo, Campo Magro, Colombo, Fazenda Rio Grande, Pinhais, Piraquara, Quatro Barras e São José dos Pinhais.

${ }^{5}$ Municípios que compõem o Segundo Anel: Balsa Nova, Bocaiúva do Sul, Contenda, Itaperuçú, Mandirituba e Rio Branco do Sul.

${ }^{6}$ Municípios que compõem o Terceiro Anel: Agudos do Sul, Campo do Tenente, Cerro Azul, Doutor Ulysses, Lapa, Piên, Quitandinha, Rio Negro, Tijucas do Sul e Tunas do Paraná.
}

Práxis Educativa, Ponta Grossa, v. 12, n. 2, p. 595-616, maio/ago. 2017 Disponível em: <http://www.revistas2.uepg.br/index.php/praxiseducativa > 
Trabalho e trabalhadores no Terceiro Anel na Região Metropolitana de Curitiba: parcialização...

De modo geral, a maioria dos municípios no Primeiro Anel apresenta bom nível de qualidade de vida e de desenvolvimento econômico (GUERRA; POCHMANN; SILVA, 2014). Esse dado pode estar relacionado às grandes indústrias que se constituíram nesses municípios, bem como o fato de estarem próximos à capital e pertenceram às grandes manchas urbanas de ocupação contínua, facilitando o deslocamento daqueles que trabalham e/ou estudam na capital. Contudo, chama a atenção o fato de Piraquara ter o menor Índice de Desenvolvimento Humano (IDH) e a maioria da população residir no campo. Além disso, há um nível bom de emprego formal, e os níveis de pobreza são baixos no que se refere a $1 \frac{1}{2}$ salário mínimo. Um índice que salta aos olhos trata do percentual dos que concluíram o Ensino Médio. Esse indicador aponta que há um baixo índice de conclusão nesses municípios. Vale destacar que o município de Piraquara apresenta índices baixos mediante os outros municípios.

A população no Segundo Anel está constituída nos espaços urbanos e rurais. Apresenta dados inferiores ao Primeiro Anel, no que diz respeito ao indicador de emprego e escolaridade (GUERRA; POCHMANN; SILVA, 2014). Essa questão pode ter relação com a distância entre os municípios e os núcleos centrais, o que implica menor acesso ao emprego formal, bem como a ausência do acesso às escolas de Ensino Médio na área rural, dado já constatado por diversos pesquisadores, entre eles Molina, Montenegro, Oliveira (2009). Há concentrações de desigualdade, de pobreza, de exclusão, mas isso não se expande para todas as partes dos municípios - os municípios de Itaperuçu, Bocaiúva do Sul e Rio Branco apresentaram baixo IDH e baixa escolaridade; além disso, o município de Itaperuçu apresenta baixa taxa de alfabetização e de emprego (GUERRA; POCHMANN; SILVA, 2014).

A população no Terceiro Anel está constituída, em sua maioria, nos espaços rurais. Esse Anel possui mais habitantes do que o Segundo Anel devido ao aumento do número de municípios pertencentes a esse eixo. Embora o número de habitantes seja superior ao Segundo Anel, não ultrapassa o número de habitantes no Primeiro Anel. Quanto ao IDH, há municípios com o nível muito baixo e municípios com alto desenvolvimento. Há uma oscilação nos níveis de desenvolvimento nesse indicador, porém os municípios com baixíssimo desenvolvimento são aqueles de difícil acesso, devido às fragilidades das estradas e do insipiente acesso ao transporte público.

Os municípios no Terceiro Anel, em sua maioria, apresentam dados inferiores ao Primeiro e Segundo Anéis, no que diz respeito aos indicadores de emprego, de pobreza, de escolaridade e de exclusão (GUERRA; POCHMANN; SILVA, 2014). Os demais índices, como desigualdade e alfabetização, oscilaram entre o nível intermediário e baixo.

Ao analisar todos os anéis, identificou-se que o Primeiro Anel, por estar próximo aos centros urbanos, apresenta indicadores mais elevados; entretanto, Piraquara possui maior população no campo e apresenta os menores índices nesse Anel. No Segundo Anel, os indicadores estão dentro da média, mas Bocaiúva do Sul, com a mesma população no campo e na cidade, Itaperuçu e Rio Branco do Sul, com a maior parte dos habitantes no urbano, apresentam baixo IDH e índice de escolaridade. No Terceiro Anel, a maioria dos índices está abaixo da média. Percebe-se que os indicadores dos municípios em que a população está concentrada em áreas rurais estão, geralmente, em um nível bem abaixo. Os municípios de Doutor Ulysses e Cerro Azul apresentam uma enorme distância diante dos municípios de outros anéis e até mesmo quando comparados ao seu próprio anel. No que diz respeito ao indicador escolaridade, a maioria dos municípios de todos os anéis estão em um nível abaixo do esperado, isso quer dizer que não estão concluindo o Ensino Médio aos 17 anos.

Práxis Educativa, Ponta Grossa, v. 12, n. 2, p. 595-616, maio/ago. 2017 Disponível em: <http://www.revistas2.uepg.br/index.php/praxiseducativa> 
Mediante esse contexto, compreende-se que o Terceiro Anel apresenta os indicadores mais baixos. Diante disso, definiu-se aprofundar o estudo nesse Anel, no que diz respeito à educação, à apropriação dos bens e à produção social dos homens e mulheres que lá vivem.

\section{Condições de trabalho no Terceiro Anel}

A política de desenvolvimento para o Terceiro Anel está vinculada a três eixos: trabalho assalariado, que mantém relações de parcialização e desqualificação do domínio dos meios de produção; agricultura familiar, voltada a atender a produção de alimentos e a subsistência e a produção agrícola ligada ao agronegócio, principalmente na exploração de reflorestamento de pinus e mineração, com intensificação da tecnologia, utilizando-se do trabalho temporário e parceiro.

O trabalho assalariado e precário assume uma importância cada vez maior na sociedade capitalista, e o preço da força de trabalho tem sido cada vez mais baixo. Para o capital só interessa o valor das coisas e não a forma de trabalho; assim, não importa o tipo de trabalho, mas o quanto ele pode ser mais produtivo. Com relação ao trabalho, pode-se dizer que Marx (2013, p. 120) defende que os homens devem organizar o trabalho conjuntamente, "[...] como criador de valores de uso, como trabalho útil, o trabalho é, assim, uma condição de existência do homem, independente de todas as formas sociais, eterna necessidade natural de mediação do metabolismo entre homem e natureza e, portanto, da vida humana".

Por sua vez, Marx (2013) assume que a forma dominante do trabalho e das relações sociais no capitalismo são mediadas pelo mercado e que elas se assemelham a relações entre coisas. Nesse sentido, o autor considera que "[...] quanto maior é a força produtiva do trabalho, menor é o tempo de trabalho requerido para a produção de um artigo, menor a massa de trabalho nele cristalizada e menor seu valor" (MARX, 2013, p. 148). Qualquer mudança na produção de determinado artigo, portanto, interfere na quantidade de trabalho e, consequentemente, no seu valor. Sob o capitalismo, o valor das coisas e o trabalho dos homens apresentam-se como "[...] relações reificadas entre pessoas e relações sociais entre coisas” (MARX, 2013, p. 148). Um exemplo disso é o salário, o qual se assenta sobre o preço do trabalho e não é definido a partir do tempo de trabalho socialmente necessário ao produtor direto.

Embora o valor e o trabalho humano sejam criados pelos homens, apresentam-se como se fossem independentes da atividade deles, sendo apenas mediadas por mercadorias, pelo dinheiro, que simbolizam relações entre coisas. Esse aspecto faz com que os homens e as mulheres ajam como produtores de mercadorias, sem consciência do valor das coisas e do seu trabalho, como se essas relações sempre tivessem sido assim. Nesse contexto, Braverman (1980) menciona:

\footnotetext{
A medida que essas formas variadas caem sob os auspícios do capital e se tornam parte do domínio de investimento lucrativo, entram para o capitalista no reino do trabalho geral ou abstrato, trabalho que amplia o capital. Na empresa moderna, todas as formas de trabalho são empregadas sem distinção e no moderno conglomerado empresarial algumas divisões recaem na indústria, outras no comércio, outras em bancos, outras em mineração e outras ainda em serviços. Todas coexistem pacificamente, e no resultado final como aparece nos balanços gerais das empresas as formas de trabalho desaparecem totalmente sob a forma de valor. (BRAVERMAN, 1980, p. 308).
}

$\mathrm{Na}$ era do capitalismo monopolista, a divisão do trabalho pode ser aplicada com o mesmo propósito às operações mecânicas e mentais (BRAVERMAN, 1980). O parcelamento do trabalho criou novas ocupações para funções cada vez mais simplificadas, rotinizadas e controladas. $\mathrm{O}$

Práxis Educativa, Ponta Grossa, v. 12, n. 2, p. 595-616, maio/ago. 2017 Disponível em: <http://www.revistas2.uepg.br/index.php/praxiseducativa > 
mesmo processo de trabalho constituído na indústria, que é a administração moderna e o uso da tecnologia, passa também a reger os outros setores de empregos.

De acordo com Braverman (1980, p. 306), “[...] os serviços constituíram grande parcela na divisão social do trabalho por toda era capitalista - para não falar nos primeiros tempos - mas não constituíram uma parte produtiva ou lucrativa senão recentemente". Quanto mais as formas de trabalho são simplificadas, parcializadas e desqualificadas, mais há alterações objetivas e subjetivas da classe trabalhadora. As alterações objetivas referem-se ao desemprego estrutural da força de trabalho e à precarização das condições de trabalho, e as alterações subjetivas caracterizam-se pela imposição de formas de controle da gestão do trabalho na perspectiva do gerencialismo.

Nesse sentido, ao consultar, em 2015, o Sistema Público de Emprego e Renda (ISPER), a Relação Anual de Informações Sociais (RAIS) e o Ministério do Trabalho e Emprego (MTE), sobre o número de empregos formais de trabalhadores homens e mulheres nos municípios do Terceiro Anel na RMC, constatou-se que há diversas atividades econômicas. Vale destacar que a descrição de atividades econômicas e do conjunto de atividades associadas a ela se baseia na Comissão Nacional de Classificação (CONCLA). Essa descrição chama a atenção por diluir-se em muitas classes, a exemplo de uma função específica cuja atividade é separar pintos entre fêmea e macho, denominada "sexagem de pintos".

Sobre a empregabilidade de trabalhadores homens no Terceiro Anel, verificou-se que o Município que mais emprega trabalhadores homens é o da Lapa, com 5.197 empregos, seguido do Município de Rio Negro, com 4.237. Doutor Ulysses é o Município com menos emprego formal, apenas 262, seguido do Município de Agudos do Sul, com 452. O Município de Doutor Ulysses apresenta o menor IDH e um dos piores índices de emprego, de pobreza, de escolaridade e de exclusão, quando comparado aos municípios do Terceiro Anel. Vale destacar que é o Município com a menor população do Terceiro Anel na RMC. Já o Município da Lapa está entre os indicadores que ficam no nível intermediário. O setor que mais empregou trabalhadores homens foi o de indústria e transformação que envolve agricultura, pecuária, produção florestal, pesca e aquicultura, com 6.730 empregos, seguido do setor comércio, com 3.726, e do setor agropecuária, com 2.106.

Por um lado, o dado do setor de indústria e transformação justifica-se, tendo em vista que a maior parte vive no campo; por outro lado, esse número é ínfimo diante da população do Terceiro Anel, que é de 149.690, e o número de empregos formais para trabalhadores homens, 18.833, representando um pouco mais de $10 \%$ no número total de habitantes. É um percentual pequeno de empregos formais. Vale destacar que a população masculina historicamente tem se tornado um depósito disponível de trabalho desempregado (BRAVERMAN, 1980).

Quanto ao emprego das mulheres, constatou-se que a Lapa é o Município que mais emprega trabalhadoras, com 4.102 empregos formais, seguido de Rio Negro, com 3.293. O Município com menos emprego é Doutor Ulysses, com 177, seguido de Adrianópolis, com 285. Essa realidade também foi constatada anteriormente sobre o número de empregos formais de trabalhadores homens. Lapa e Rio Negro são os municípios mais populosos do Terceiro Anel, o que justifica o maior número de empregos; além disso, há diversas indústrias, como Seara alimentos, Naturalat, Above Metalúrgica, Usina de Potencial Biodiesel, Souza Cruz S.A., entre outras. O setor que mais empregou as trabalhadoras, em 2013, foi o de administração pública, com 3.997, seguido do comércio, com 2.534, e da indústria de transformação, com 1.098.

Há um movimento contrário entre os postos de trabalho de homens e mulheres, pois as trabalhadoras estão concentradas na administração pública e no comércio e depois na indústria e 
transformação. Já os trabalhadores homens estão concentrados no setor de indústria e transformação, que significa o trabalho com a agricultura. Apesar de os postos serem contrários, na essência representam parte do mesmo fenômeno. Certamente os trabalhadores homens estão nessa frente para executar trabalho braçal, e as mulheres estão na administração para executar o trabalho manual ou mental. Entretanto, a divisão do trabalho é aplicada a homens e a mulheres da mesma forma, porque o fundamento é converter tudo em instruções rígidas e específicas para cada rotina (BRAVERMAN, 1980), de forma a baratear cada vez mais o trabalho assalariado e converter o processo de trabalho sob o domínio da tecnologia.

Entretanto, há uma nova forma de ser do trabalho feminino, o qual se fundamenta de menor qualificação e no trabalho intensivo. Além disso, há uma dupla exploração pelo capital, pois, além de trabalhar no "[...] espaço público, fabril e de serviços, ela realiza [o] trabalho doméstico, garantindo a esfera da reprodução societal, esfera não diretamente mercantil, mas indispensável para a reprodução do sistema" do capital (ANTUNES, 2008, p. 119).

De modo geral, o número de empregos formais para mulheres, em 2013, foi de $13.260 \mathrm{e}$ para os homens foi de 18.833. O número total de ocupações entre homens e mulheres foi de 32.093, considerando a população de 149.690 do Terceiro Anel - esse valor representa um pouco mais de $20 \%$.

Quanto ao emprego formal na agropecuária entre 2007 a 2013, os dados revelam que, na maioria dos municípios, houve queda de emprego no setor mencionado. Essa queda tem relação com as alterações nos processos de trabalho e com as novas formas de organização da produção, principalmente pelo avanço científico e técnico que, sob relações capitalistas, tem servido contra o próprio trabalhador gerando desemprego e super exploração (FRIGOTTO, 2014). Se de um lado há dispensa de força de trabalho na agricultura; por outro, há absorção de novas ocupações "[...] de aproveitamento de recursos naturais [que] instiga novos processos e formas sociais de trabalho, o que requer incluir aí, o caráter de extração de sobre trabalho camuflado no disfarce da busca de novas alternativas não agrícolas" (LUSTOSA, 2012, p. 63).

Por sua vez, a alta rotatividade por setores de atividade econômica, segundo o DIEESE (2014, p. 8), concentra-se na Construção Civil, com 115,0\%, e na Agricultura, com 88,8\%. Os outros setores são menos expressivos quanto à rotatividade, como Comércio (64,2\%), Serviços (59,6\%), Administração Pública (56,0\%), Indústria de Transformação (52,4\%), Serviços de Utilidade Pública (32,5\%) e Extrativa Mineral (31,9\%). De qualquer forma, essas taxas são expressivas, pois revelam que há uma redução dos contratos de trabalho.

Em síntese, os dados sobre o emprego formal dos trabalhadores no Terceiro Anel, na RMC, mostram que as formas de emprego são classificadas por setores e estão cada vez mais parcializadas e desqualificadas; há redução do emprego formal em todos os setores mencionados; há queda de emprego na agropecuária, devido ao avanço científico e técnico; há absorção de novas ocupações de trabalho, o trabalho feminino está concentrado na administração e no comércio, e o trabalho masculino, na indústria de transformação que trata da agricultura. Esses dados revelam que a produção social dos homens na atual conjuntura da reestruturação produtiva tem como forma dominante o trabalho assalariado que se constitui de forma massificada, barata e reforça as mistificações do salário. Como menciona Marx (2013),

[...] a importância decisiva da transformação do valor e do preço da força de trabalho na forma-salário ou em valor e preço do próprio trabalho. Sobre essa forma de manifestação, que torna invisível a relação efetiva e mostra precisamente o oposto dessa relação, repousam todas as noções jurídicas, tanto do trabalhador como do capitalista, todas as suas ilusões de liberdade, todas as tolices apologéticas da economia vulgar. (MARX, 2013, p. 610).

Práxis Educativa, Ponta Grossa, v. 12, n. 2, p. 595-616, maio/ago. 2017 Disponível em: < http://www.revistas2.uepg.br/index.php/praxiseducativa > 
Marx demonstra que o salário é o fundamento das bases legais, das mistificações e das ilusões de liberdade, pois dá a impressão que todo o trabalho foi pago com o salário. Por sua vez, essa relação não se manifesta diretamente ao trabalhador familiar, que não se submete inteiramente à extração de mais valia. Assunto analisado a seguir.

\section{Condições de trabalho do trabalhador familiar no Terceiro Anel}

O Terceiro Anel é onde se concentra o maior número de estabelecimentos da agricultura familiar, sendo superior à soma do Primeiro e Segundo Anéis. Dados do Ministério do Desenvolvimento Agrário (MDA) apontam que, no Paraná, a agricultura familiar representa 82\% do número de estabelecimentos na agropecuária e 70\% do pessoal ocupado. Esse segmento pratica a agricultura de subsistência e a produção de alimentos voltada ao abastecimento interno e à segurança alimentar; por outro lado, também está associado ao grande capital (NEAD, 2008).

No Censo Agropecuário de 2006, foram identificados 4.367 .902 estabelecimentos da agricultura familiar por todo o país, o que representa $84,4 \%$ dos estabelecimentos.

Esse numeroso contingente de agricultores familiares ocupava uma área de 80,25
milhões de hectares, ou seja, $24,3 \%$ da área ocupada pelos estabelecimentos
agropecuários brasileiros. Esses resultados mostram uma estrutura agrária ainda
concentrada no País: os estabelecimentos não familiares, apesar de representarem
15,6\% do total dos estabelecimentos, ocupavam $75,7 \%$ da área ocupada. A área média
dos estabelecimentos familiares era de 18,37 hectares, e a dos não familiares, de 309,18
hectares. (IBGE, 2006, p. 19).

Apesar de a agricultura familiar ser predominante no país, ela ocupa uma área muito pequena diante das áreas dos estabelecimentos patronais.

Quanto ao número de estabelecimentos agropecuários no Terceiro Anel, a Tabela 1 apresenta o tipo de produtor e a quantidade, porém são variáveis que derivaram do Censo Agropecuário em 2006, mas só foram disponibilizadas em 2009. A outra variável na Tabela 1, sobre o Médio Produtor, foi disponibilizada no site do IBGE em 2014 (ZANCHET, 2010).

Tabela 1 - Número de estabelecimentos agropecuários ${ }^{7}$ no Terceiro Anel na Região Metropolitana de Curitiba

\begin{tabular}{|c|c|c|c|c|c|}
\hline Município & $\begin{array}{c}\text { Agricultura } \\
\text { Familiar - } \\
\text { PRONAF } \\
2006\end{array}$ & $\begin{array}{c}\text { Agricultura } \\
\text { Familiar - } \\
\text { PRONAF } \\
2015\end{array}$ & $\begin{array}{c}\text { Familiar - } \\
\text { não } \\
\text { PRONAF } \\
2006\end{array}$ & $\begin{array}{l}\text { Não familiar, } \\
\text { módulo fiscal } \\
\text { Médio } \\
\text { Produtor } \\
2006 \\
\end{array}$ & $\begin{array}{c}\text { Outros não } \\
\text { classificados } \\
2006\end{array}$ \\
\hline Adrianópolis & 752 & 400 & 72 & 31 & 88 \\
\hline $\begin{array}{l}\text { Agudos do } \\
\text { Sul }\end{array}$ & 1.126 & 605 & 86 & 13 & 121 \\
\hline $\begin{array}{l}\text { Campo do } \\
\text { Tenente }\end{array}$ & 216 & 273 & 14 & 18 & 44 \\
\hline Cerro Azul & 1.832 & 1.448 & 115 & 49 & 254 \\
\hline $\begin{array}{l}\text { Doutor } \\
\text { Ulysses }\end{array}$ & 555 & 551 & 19 & 27 & 55 \\
\hline
\end{tabular}

\footnotetext{
${ }^{7}$ Segundo o Censo Agropecuário de 2006, estabelecimento agropecuário é a unidade de produção que emprega total ou parcialmente atividades agropecuárias, aquícolas e florestais, submetidas à administração do produtor ou do empregador, localizada em área rural ou urbana, cuja finalidade pode ser a subsistência ou a venda, formando uma unidade recenseável (IBGE, 2006).
}

Práxis Educativa, Ponta Grossa, v. 12, n. 2, p. 595-616, maio/ago. 2017 Disponível em: <http://www.revistas2.uepg.br/index.php/praxiseducativa> 
Patrícia Correia de Paula Marcoccia e Maria de Fátima Rodrigues Pereira

\begin{tabular}{cccccc}
\hline Lapa & 2.244 & 1.492 & 159 & 237 & 236 \\
Piên & 1.035 & 899 & 58 & 10 & 37 \\
Quitandinha & 1.800 & 1.247 & 66 & 21 & 117 \\
Rio Negro & 880 & 806 & 78 & 33 & 63 \\
Tijucas do Sul & 818 & 650 & 39 & 40 & 89 \\
$\begin{array}{c}\text { Tunas do } \\
\text { Paraná }\end{array}$ & 236 & 200 & 13 & 4 & 19 \\
Total & 11.494 & 8.571 & 719 & 483 & 1.123 \\
\hline
\end{tabular}

Fonte: IBGE Censo Agropecuário (2006). Dados disponibilizados pelo IPARDES (2015) e pela Empresa de Assistência Técnica e Extensão Rural (EMATER-PR) (2015). Elaborada pelas autoras.

Os dados da Tabela 1 que tratam da Agricultura Familiar ${ }^{8}$ com PRONAF $^{9}$ consideram como agricultor familiar aqueles que dirigem o processo de produção, trabalham e se utilizam de mão de obra familiar no seu estabelecimento que tem até quatro módulos fiscais. Referente ao ano de 2006, no Terceiro Anel, na RMC, verifica-se um total de 11.494 estabelecimentos de Agricultura Familiar. Em 2015, essa realidade foi alterada, pois houve redução no número de estabelecimentos da Agricultura Familiar com PRONAF para 8.571. Sobre os estabelecimentos sem PRONAF, em 2006, foram identificados 719.

Quanto ao estabelecimento de agricultor familiar na condição de médio produtor - que diz respeito ao regime familiar, mas demanda a contratação de empregado, constituindo, assim, o emprego rural, que pode ser caracterizado como permanente, temporário, parceiro ${ }^{10}$ ou outra condição -, foi identificado que, em 2006, houve 483 estabelecimentos que se utilizaram dessa condição. Os outros considerados como "não classificados", em 2006, representavam 1.123 estabelecimentos. A categoria "outros não classificados" foram aqueles que não se enquadraram como agricultor familiar e médio produtor. Por outro lado, essa categoria diz respeito aos grandes capitalistas, seja por extensão de terra ou por valor da produção. Vale lembrar que o Paraná é o segundo produtor de soja no país e sua economia está sustentada na exportação de commodities, como soja e milho.

Os dados supracitados sobre a agricultura familiar em 2006 revelam que, no Terceiro Anel, se concentram 12.696 estabelecimentos da agricultura familiar, dado superior à soma do Primeiro e Segundo Anéis, que representa 11.478.

De acordo com a Tabela 1, de 2006 para cá houve redução no número de estabelecimentos da agricultura familiar. Pode-se inferir, assim, que as mudanças na forma de produção têm alterado essa realidade, e, também, porque o capital quando não tem interesse em se juntar à agricultura familiar, isto é, quando não é rentável para ele, este dissemina os trabalhadores familiares. Por sua vez, quando tem interesse na agricultura familiar é no sentido de produzir no trabalhador familiar a sujeição à proletarização, por meio da integração plena.

De acordo com o Censo de 2006, 79,01\% de estabelecimentos de agricultura familiar receberam recursos do PRONAF, que foi responsável por 32,07\% dos recursos de financiamento e $65,75 \%$ tiveram origem em outros programas federal, estadual e municipal; e "[...] 19,73\% dos

\footnotetext{
8 A Lei no 11.326, da Agricultura Familiar, foi instituída em 24 de julho de 2006.

9 O Programa Nacional de Fortalecimento da Agricultura Familiar (PRONAF) visa o fortalecimento do agricultor familiar, de forma a integrá-lo ao agronegócio para que amplie a renda, o valor do seu produto e de sua propriedade, mediante apropriação de novas bases técnicas e científicas de produção, de valorização do produtor rural e de profissionalização dos produtores familiares.

${ }^{10} \mathrm{O}$ trabalhador parceiro é aquele que está sujeito ao produtor ou capataz e realiza as atividades sob o recebimento de uma cota-parte da produção (ZANCHET, 2010).
}

Práxis Educativa, Ponta Grossa, v. 12, n. 2, p. 595-616, maio/ago. 2017 Disponível em: <http://www.revistas2.uepg.br/index.php/praxiseducativa> 
Trabalho e trabalhadores no Terceiro Anel na Região Metropolitana de Curitiba: parcialização...

estabelecimentos declararam ter recebido tais recursos" (IBGE, 2006, p. 164). A maioria dos agricultores familiares eram proprietários das terras, os quais obtiveram seus financiamentos aprovados nos bancos, cuja finalidade foi investir na produção.

Esse movimento representa a integração do pequeno produtor ao grande capital, pois, para investir na sua produção, necessita se aliar ao governo (políticas) e aos bancos. Esse processo expressa o interesse do capital em homogeneizar todos os que trabalham na agricultura, ou seja, integrá-los de modo que se sintam parte de um mesmo projeto de desenvolvimento para o campo. O trabalhador familiar submete-se ao capital, o qual mascara que estão sob o mesmo espaço político, sem revelar as desigualdades entre eles. Aparentemente não há como diferenciálos, mas, na essência, há profundos processos excludentes que os expropriam da riqueza e da renda que é menor na agricultura familiar. Por outro lado, são responsáveis pela maior parte da produção que envolve a diversificação de alimentos e boa parte da pecuária no território local.

Os dados levantados por Fernandes (2013, p. 204) reafirmam isso, “[...] porque $74 \%$ dos agricultores recebem somente $15 \%$ do crédito agrícola, possuem apenas $24 \%$ da área agricultável, mas produzem 38\% do valor bruto", constituído por "[...] 2 milhões de famílias que têm uma renda mensal em torno de 15 dólares". As políticas de crédito geralmente têm contribuído para o endividamento dos trabalhadores familiares. Além disso, quase não há acesso a tecnologias apropriadas para as pequenas propriedades, a não ser se estiverem associados ao agronegócio.

Molina, Montenegro e Oliveira (2009, p. 9) apontam que os piores índices de renda estão no campo, "[...] somente 5,5\% alcançam rendimento mensal acima de 3 salários mínimos", a partir dos 10 anos ou mais de idade, economicamente ativos. Na cidade, "[...] nesta mesma faixa de renda localizam-se 31,8\% da população”. A baixa renda interfere profundamente na trajetória escolar dos trabalhadores do campo, reforçando o analfabetismo e/ou baixo nível de escolaridade, repercutindo na evasão e na distorção idade-série.

Diferentemente da agricultura familiar, o agronegócio "[...] fica com 85\% do crédito agrícola, controla $76 \%$ da área agricultável, produz $62 \%$ do valor bruto e emprega $26 \%$ das pessoas" (FERNANDES, 2013, p. 204). Esses dados revelam a extrema concentração de terra e renda do campo brasileiro, sendo essas terras dominadas por grandes corporações que se unem aos bancos, os quais impõem sua dominação na política de desenvolvimento da agricultura, que, por sua vez, é absorvida pelo Estado, responsável por regular as esferas do governo para atender a ideologia do capital e da propriedade.

Embora a realidade do agronegócio seja dominante, os dados supracitados revelam que a agricultura familiar tem uma participação importante no projeto de desenvolvimento do campo e do país, particularmente porque é ela que produz a diversificação de alimentos. O Censo Agropecuário de 2006 aponta que a agricultura familiar "[...] é responsável por garantir boa parte da segurança alimentar do país, como importante fornecedora de alimentos para o mercado interno" (IBGE, 2006, p. 25), a saber:

$87,0 \%$ da produção nacional de mandioca, $70,0 \%$ da produção de feijão (sendo $77,0 \%$ do feijão-preto, $84,0 \%$ do feijão fradinho, caupi, de corda ou macáçar e $54,0 \%$ do feijão de cor), 46,0\% do milho, 38,0\% do café (parcela constituída por 55,0\% do tipo robusta ou conilon e $34,0 \%$ do arábica), $34,0 \%$ do arroz, $58,0 \%$ do leite (composta por $58,0 \%$ do leite de vaca e $67,0 \%$ do leite de cabra), possuíam 59,0\% do plantel de suínos, $50,0 \%$ do plantel de aves, 30,0\% dos bovinos, e produziam $21,0 \%$ do trigo. A cultura com menor participação da agricultura familiar foi a da soja $(16,0 \%)$, um dos principais produtos da pauta de exportação brasileira. (IBGE, 2006, p. 20).

Práxis Educativa, Ponta Grossa, v. 12, n. 2, p. 595-616, maio/ago. 2017 Disponível em: <http://www.revistas2.uepg.br/index.php/praxiseducativa> 
Se, por um lado, a agricultura familiar é responsável pela segurança alimentar do país, esta tem sido integrada às estruturas nacionais de mercado, em que não é alterada apenas a base técnica, mas também as relações sociais que transformam o trabalhador familiar em agricultores profissionais. Conforme aponta Abramovay (2012, 137-138), “[...] aquilo que era antes de tudo um modo de vida converte-se numa profissão, numa forma de trabalho. O mercado adquire a fisionomia impessoal com que se apresenta aos produtores numa sociedade capitalista".

De acordo com Abramovay (2012), o qual corrobora com a integração do pequeno produtor ao grande produtor, a sobrevivência do agricultor familiar depende de sua integração ao capital, que significa se profissionalizar e aperfeiçoar tecnologicamente sua produção. Ora, a integração total, sob a lógica do mercado, tem uma feição impessoal, que produz nesse trabalhador espírito de competitividade e eficiência. Por sua vez, esse movimento produz diversas formas de submissão ao capital, pois o trabalhador familiar está em condições desiguais em termos de domínio dos meios de produção, da propriedade da terra, de acesso às políticas agrícolas de crédito e de financiamentos.

Aqueles trabalhadores familiares que não acompanharem a escala de produção acabarão sendo expropriados de suas terras e do seu trabalho. Embora, aparentemente, esse processo separe o trabalhador familiar que se associa ao capital e o trabalhador que não consegue servi-lo, considera-se que eles pertencem à classe que vive do seu trabalho.

A tendência da agricultura familiar, nesse contexto, é flexibilizar o trabalho e proletarizar o trabalhador familiar, submetendo-o ao comando do capital, o qual os quer apenas como produtor de mercadorias. Esse movimento efetiva-se por meio das políticas públicas e programas governamentais, a exemplo do PRONAF, cuja lógica é difundir que não há oposição entre o grande capital e a agricultura familiar, pois os dois se compõem em um mesmo movimento. Sob essa perspectiva, o trabalhador familiar, para sobreviver, precisa estar unido a esse processo e acatá-lo.

Nesse cenário, identificou-se a condição dos empregados que estão trabalhando nos estabelecimentos agropecuários no Terceiro Anel, na RMC. São trabalhadores que possuem 14 anos ou mais e não apresentam laço de parentesco com o produtor, havendo, em 2006, 1.740 empregados na condição de permanentes, 2.144 na condição de temporários, 49 empregados parceiros e 13 empregados em outra condição. Somando o número de empregados temporários e parceiros, tem-se 2.193 trabalhadores que são contratados para trabalhar nos estabelecimentos agropecuários uma ou mais vezes, de acordo com a demanda do empregador. Essa realidade apresentada sobre a predominância do trabalho temporário expressa-se também no estado do Paraná:

Em 2006, os produtores recenseados informaram a contratação de 131.711 empregados temporários, o que representa $54,7 \%$ do total. [...]. Na categoria de empregado permanente [...] estão 102.660 pessoas contratadas, ou 42,6\% do total. [...]. O empregado-parceiro representa [...] apenas 4.658 pessoas ocupadas ou $1,9 \%$ do total. [A] categoria outra condição [...] se apresenta pouco representativa no total de empregados. (ZANCHET, 2010, p. 166).

De modo geral, os estabelecimentos que contrataram os empregados mencionados são aqueles que contratam menos de cinco pessoas e são "[...] responsáveis por 37\% do total de empregos e, provavelmente, ligados à agricultura familiar" (ZANCHET, 2010, p. 166). Vale destacar que o agricultor familiar que se enquadra no PRONAF pode ter até dois empregados permanentes.

Práxis Educativa, Ponta Grossa, v. 12, n. 2, p. 595-616, maio/ago. 2017 Disponível em: <http://www.revistas2.uepg.br/index.php/praxiseducativa> 
Trabalho e trabalhadores no Terceiro Anel na Região Metropolitana de Curitiba: parcialização...

A agroindústria também é responsável pela contratação de um amplo número de empregados, seja na forma de emprego permanente ou temporário. Nesse sentido, Antunes (2011) evidencia um movimento contraditório, processual e multiforme de desqualificação do trabalho e subproletarização em setores situados na periferia, em que há um numeroso grupo de trabalhadores reserva, aptos para assumirem trabalho informal, temporário, parcial e subcontrato.

Verifica-se que os estabelecimentos agropecuários estão necessitando cada vez menos do emprego permanente e mais do emprego temporário, que aparece pela face de um trabalho parcializado e precarizado, cuja finalidade é "[...] intensificar as formas de extração do sobretrabalho em tempo cada vez mais reduzido" (ANTUNES, 2011, 120-121).

O capital busca adequar trabalhadores flexíveis para constituir um trabalhador supérfluo, ou seja, um trabalhador que se submete a um salário mais baixo sob pena de perder o emprego e viver na miséria. Esse movimento está sendo conduzido por diversos sindicatos que, ideologicamente, difundem a diminuição do tempo de trabalho e a subordinação do trabalhador para que este seja obrigado a aceitar um salário menor porque há vários trabalhadores de reserva (ANTUNES, 2008).

A Tabela 2 que segue apresenta dados sobre o pessoal ocupado em estabelecimento agropecuário, nas empresas rurais ou na condição de médio produtor, sem laço de parentesco com o produtor e com laço de parentesco.

Tabela 2 - Pessoal ocupado ${ }^{11}$ em estabelecimentos agropecuários com ou sem laço de parentesco no Terceiro Anel na RMC

\begin{tabular}{|ccc}
\hline Municípios & Sem laço de parentesco & Com laço de parentesco \\
\hline Adrianópolis & 357 & 1.996 \\
\hline Agudos do Sul & 188 & 2.732 \\
Campo do Tenente & 523 & 773 \\
\hline Cerro Azul & 209 & 5.100 \\
\hline Doutor Ulysses & 164 & 1.649 \\
\hline Lapa & 2.043 & 7.068 \\
\hline Piên & 470 & 3.333 \\
\hline Quitandinha & 594 & 4.891 \\
\hline Rio Negro & 651 & 3.196 \\
Tijucas do Sul & 3.245 & 1.778 \\
\hline Tunas do Paraná & 73 & 605 \\
\hline Total & 8.517 & 33.121 \\
\hline
\end{tabular}

Fonte: IBGE Censo Agropecuário (2006). Dados disponibilizados pelo IPARDES (2015). Elaborada pelas autoras.

Os dados da Tabela 2 apontam que, muito embora o estabelecimento não seja da agricultura familiar, o número de pessoal ocupado com laço de parentesco foi alto em 2006, totalizando 33.121, e o número de trabalhadores sem laço de parentesco foi de 8.517. Esses estabelecimentos reúnem familiares que não são remunerados, mas ajudam as pessoas da família, diferentemente da situação dos empregados, os quais podem ser permanentes, temporários, parceiros ou outra condição.

\footnotetext{
11 O conceito de pessoa ocupada, segundo a Pesquisa Nacional por Amostra de Domicílio (PNAD), refere-se a três perspectivas de ocupação, a saber: em que há algum tipo de remuneração; sem remuneração, pois trata de membro de unidade domiciliar; e para a própria alimentação.
} 
A Tabela 3 apresenta dados sobre o número de parentes que trabalham com o produtor nesses estabelecimentos.

Tabela 3 - Pessoal ocupado em estabelecimento agropecuário em 31/12 com agricultura familiar com laço de parentesco com o produtor no Terceiro Anel na RMC

\begin{tabular}{ccccccc}
\hline Municípios & $\begin{array}{c}\text { Total de } \\
\text { pessoas }\end{array}$ & 1 pessoa & $\begin{array}{c}\text { De 2 a 3 } \\
\text { pessoas }\end{array}$ & $\begin{array}{c}\text { De 4 a 5 } \\
\text { Pessoas }\end{array}$ & $\begin{array}{c}\text { De 6 a 9 } \\
\text { pessoas }\end{array}$ & $\begin{array}{c}\text { De 10 pessoas } \\
\text { e mais }\end{array}$ \\
\hline Adrianópolis & 1.725 & 312 & 927 & 347 & 129 & 10 \\
\hline $\begin{array}{c}\text { Agudos do } \\
\text { Sul }\end{array}$ & 2.477 & 460 & 1.379 & 478 & 160 & - \\
$\begin{array}{c}\text { Campo do } \\
\text { Tenente }\end{array}$ & 564 & 85 & 229 & 157 & 93 & - \\
\hline $\begin{array}{c}\text { Cerro Azul } \\
\text { Doutor }\end{array}$ & 4.498 & 694 & 2.087 & 1.133 & 542 & 42 \\
Ulysses & 1.442 & 193 & 574 & 417 & 248 & 10 \\
$\quad$ Lapa & 5.941 & 502 & 3.302 & 1.703 & 377 & 57 \\
$\quad$ Piên & 3.208 & 115 & 1.527 & 1.203 & 363 & - \\
\hline $\begin{array}{c}\text { Quitandinha } \\
\text { Rio Negro }\end{array}$ & 4.530 & 465 & 2.480 & 1.183 & 335 & 67 \\
\hline $\begin{array}{c}\text { Tijucas do } \\
\text { Sul }\end{array}$ & 1.453 & 100 & 1.299 & 1.156 & 292 & 52 \\
$\begin{array}{c}\text { Tunas do } \\
\text { Paraná }\end{array}$ & 573 & 248 & 838 & 267 & 60 & 40 \\
Total & 29.310 & 3.251 & 14.823 & 8.214 & 2.707 & 37 \\
\hline
\end{tabular}

Fonte: IBGE Censo Agropecuário (2006). Dados disponibilizados pelo IPARDES (2015). Elaborada pelas autoras.

Sobre o número de parentes que trabalham com o produtor em estabelecimento agropecuário, em 2006, verificou-se que há predominância entre 2 a 3 familiares que trabalham com laço de parentesco na agricultura familiar, totalizando 14.823, seguido de 4 a 5 familiares, com 8.214, e 1 familiar, com 3.251.

Não foi identificado se a produção na agricultura familiar foi para subsistência ou se foi distribuída para comercialização. Zanchet (2008, p. 22-26) fez um estudo sobre as ocupações no Paraná, o qual menciona que, na produção animal, há um crescimento dos trabalhadores por conta própria, juntamente aos "[...] membros não-remunerados, representam mais de $60 \%$ do total de pessoas ocupadas na criação de bovinos. Por outro lado, na produção de hortaliças mais de $70 \%$ do pessoal ocupado é para o consumo próprio", embora haja um importante segmento de produtores nessa área com atividade mercantil (ZANCHET, 2008). Para a autora, a agricultura familiar representa $66,6 \%$ de pessoas ocupadas por conta própria e não-remunerados, sendo $22,8 \%$ na criação de bovinos, $11,1 \%$ na soja e $10,8 \%$ no fumo.

De todo modo, esse dado é relevante, pois, se apenas 2 a 3 parentes estão envolvidos com o trabalho na agricultura familiar, no Terceiro Anel, na RMC, infere-se que os outros familiares, se houver, estão trabalhando em outros estabelecimentos para complementar a renda, tendo em vista que boa parte da agricultura familiar pode estar sendo direcionada ao consumo próprio, conforme aponta Zanchet (2008). Nesse caso, considera-se que não é possível reproduzir as condições de vida somente com a agricultura familiar, implicando a necessidade de outros familiares buscarem outros empregos.

Quanto à condição do produtor, se está associado à cooperativa e/ou à entidade de classe, constatou-se que, em 2006, dos 13.615 estabelecimentos, apenas 3.411 produtores são 
associados à cooperativa e/ou à entidade de classe. No que diz respeito à cooperativa, há 828 estabelecimentos associados. Sobre os associados à entidade de classe, há 2.200. E os associados à cooperativa e à entidade de classe representam 383 produtores. Chama a atenção que 10.204 produtores não estão associados a nenhuma entidade no Terceiro Anel na RMC. Vale destacar que há sindicatos de trabalhadores rurais nos municípios do Terceiro Anel da RMC, como FETAEP $^{12}$ e FETRAF-Sul, essa última em um número reduzido.

A FETAEP realiza as formações junto ao $\operatorname{SENAR}^{13}$, que possui convênio de cooperação técnico-financeiro desde 2004. Os recursos financeiros para as formações de dirigentes sindicais e de trabalhadores rurais no âmbito estadual, regional e municipal vêm do SENAR, mantido pelas entidades patronais. Essas entidades identificam-se com as políticas públicas, com os programas governamentais para a agricultura familiar que, conforme mencionado, estão vinculadas ao grande capital, pois, embora aparentemente revelem preocupação com os trabalhadores do campo, com as suas condições de vida, o fazem sob a lógica do capital financeiro e da ideologia neoliberal. O SENAR, por exemplo, nos últimos anos, estabeleceu novas parcerias, entre elas com o Governo Federal, pelo Programa Nacional de Acesso ao Ensino Técnico e Emprego (PRONATEC), destinado a jovens e adultos. Esse programa é realizado junto aos Institutos Federais de Educação Ciência e Tecnologia, os quais estão disseminados no interior dos estados, geralmente em áreas consideradas rurais ou próximas a elas. Alguns cursos implementados são na perspectiva da agroecologia com princípios de gestão da agroindústria.

A concepção de educação do SENAR visa profissionalizar o trabalhador familiar, formálo sob a base empresarial para que se torne um empreendedor e se integre ao mercado. Os que não conseguirem se adaptar serão considerados ineficientes e sem espírito competitivo. Nesse sentido, a formação do trabalhador familiar visa à formação de um trabalhador qualificado aos interesses da classe dos empresários que disputam os processos de formação profissional, os currículos dos cursos de Ensino Médio Integrado e Ensino Superior, voltados ao empreendedorismo e à gestão do agronegócio. Nesse contexto, o processo de escolarização desse trabalhador não é para formar alguém produtor de conhecimento, mas apenas para se tornar produtor de mercadorias.

Os dados analisados revelam que o trabalho no Terceiro Anel na RMC se apresenta de forma parcializada, desqualificada e precarizada. Esse processo também influencia as entidades de classe e as cooperativas, que apontam para redução dos produtores em se associar às entidades sociais. Esse dado também pode ser analisado sob a perspectiva de que, se há pouca articulação coletiva nesses municípios, provavelmente há uma ocupação densa do capital nesses territórios, tendo em vista que ele se transfere para locais em que encontram menores resistências para explorar a terra e a força de trabalho. Os produtores estão cada vez mais individualizados porque essas entidades não estão fortalecendo suas demandas.

Para Antunes (2008), há uma crise sindical mundial que aponta para um movimento de individualização das relações de trabalho, de um sindicalismo subordinado ao comando do patronal, bem como “[...] crescente burocratização e institucionalização das entidades sindicais

\footnotetext{
${ }^{12}$ Federação dos Trabalhadores na Agricultura do Estado do Paraná (FETAEP). É uma entidade sindical de “[...] segundo grau constituída para representar legalmente a categoria profissional dos trabalhadores rurais" (FETAEP, 2013). Esses trabalhadores compreendem: assalariados permanentes e temporários, agricultores familiares pequenos proprietários, arrendatários, meeiros e parceiros entre outros. Possui 308 sindicatos filiados no Paraná e essa entidade faz parte do sistema da Confederação Nacional dos Trabalhadores na Agricultura (CONTAG).

13 O Serviço Nacional de Aprendizagem Rural (SENAR) foi criado pela Lei no 8.315, de 23 de dezembro de 1991. É uma entidade que integra o Sistema S, de direito privado, paraestatal, mantida pela classe patronal rural, vinculada à Confederação da Agricultura e Pecuária do Brasil (SENAR, 2014).
}

Práxis Educativa, Ponta Grossa, v. 12, n. 2, p. 595-616, maio/ago. 2017 Disponível em: <http://www.revistas2.uepg.br/index.php/praxiseducativa> 
que se distanciam dos movimentos sociais autônomos" (ANTUNES, 2008, p. 70), em decorrência de ações anticapitalistas e da luta contra o capital.

Em síntese, há pouca articulação coletiva entre os produtores e, ao mesmo tempo, uma mínima representação, a qual está vinculada ao patronato rural por meio do SENAR. Essa situação desmobiliza os trabalhadores familiares que são predominantes no Terceiro Anel na RMC. Por outro lado, há movimentos de trabalhadores do campo com identidade de luta de classes na RMC vinculados ao Movimento dos Trabalhadores Sem Terra MST, localizado no Contestado, no Município da Lapa, comunidades faxinalenses em Mandirituba, comunidades indígenas em Piraquara e comunidades quilombolas em Adrianópolis e Bocaiúva do Sul.

Sobre o nível de instrução da pessoa que dirige o estabelecimento agropecuário, em 2006, de um total de 13.615 produtores, 8.272 possuem Ensino Fundamental incompleto, 862 cursaram Alfabetização de Adultos, 1.350 têm o Ensino Fundamental completo, 215 possuem Ensino Médio Completo (técnico agrícola), 813 têm Ensino Médio completo, 60 possuem formação superior (Engenheiro Agrônomo, Veterinário, Zootecnista, Engenheiro Florestal), 180 têm outra formação superior, 778 não tiveram acesso à escola, mas sabem ler e escrever, e 1085 produtores não sabem ler e escrever. Esses dados revelam que o nível educacional desses produtores é extremamente baixo, se considerar-se que a maioria das pessoas que dirige os estabelecimentos agropecuários tem o Ensino Fundamental Incompleto.

Outro dado que elucida isso é o analfabetismo entre os produtores, situação que traz consequências graves no que diz respeito às posições e às condições de trabalho. Nesse mesmo processo, está o acesso e a conclusão do Ensino Médio e da Educação Superior. A oferta de matrícula no campo brasileiro está "[...] entre os anos iniciais e finais do ensino fundamental [é] para duas vagas nos anos iniciais, [e] uma nos anos finais" (MOLINA; MONTENEGRO; OLIVEIRA, 2009, p. 28). Em relação aos anos finais do Ensino Fundamental e o Ensino Médio, constata-se que há "[...] seis vagas nos anos finais correspondendo a apenas uma vaga no ensino médio” (MOLINA; MONTENEGRO; OLIVEIRA, 2009, p. 28).

O baixo acesso dos trabalhadores do campo aos diferentes níveis de ensino é parte da história da formação do campo brasileiro, revelando as persistentes desigualdades educacionais e a vida econômica e política que foi estabelecida para essa população. A educação escolar que chega aos trabalhadores familiares é mínima, apenas para sua sobrevivência. Pode-se inferir, portanto, que há dois movimentos que se expressam no Terceiro Anel, na RMC, a saber: a) se a maioria dos trabalhadores familiares possui baixa escolaridade, em decorrência, seu trabalho é para subsistência, tendo em vista que estes municípios são de difícil acesso aos centros urbanos em que, geralmente, é realizada a comercialização dos seus produtos; ou b) esse trabalhador familiar vende seus produtos para um "terceiro", o qual adquire por um valor mínimo. Esses movimentos acarretam submissão nas mais diversas condições de trabalho e de remuneração.

Esse retrato estende-se, também, para as pessoas ocupadas de 10 anos ou mais em atividades agrícolas no Terceiro Anel, as quais estão predominantemente entre a ausência de instrução e o Ensino Fundamental incompleto, representando 22.467. Entre o Ensino Fundamental completo e o Ensino Médio incompleto, há 4.319 pessoas; entre o Ensino Médio completo e o Ensino Superior incompleto, há 2.917 pessoas; com o Ensino Superior completo, há 402 pessoas; e, por fim, os não determinados representam 90 pessoas.

Se os trabalhadores familiares, em sua maioria, tiveram acesso somente a um tipo de Educação Básica, elementar para o campo, isso significa que são trabalhadores pobres, que produziram sua existência material de forma precária, portanto precisavam atender as suas necessidades básicas. Assim, as condições para estudar, o tipo de educação, a formação e o

Práxis Educativa, Ponta Grossa, v. 12, n. 2, p. 595-616, maio/ago. 2017 Disponível em: <http://www.revistas2.uepg.br/index.php/praxiseducativa $>$ 
Trabalho e trabalhadores no Terceiro Anel na Região Metropolitana de Curitiba: parcialização...

conhecimento a que tiveram acesso foram frágeis, escassos, provavelmente não possibilitaram que pudessem fruir do conhecimento produzido pela humanidade, pelo contrário, tratou-se da privação do direito à educação. No campo, essa privação expressa-se de forma mais aguda, ou seja, há mais ausência no acesso e há pouca fruição do conhecimento. Vale ressaltar que os problemas que o trabalho enfrenta hoje são os mesmos no campo e na cidade, porque os dois estão sob relações capitalistas, sob o monopólio do capital industrial, financeiro e comercial, os quais se juntam para disputar com o trabalho. No entanto, para produzir valor, necessitam da força de trabalho assalariada.

\section{Desafios na apropriação da educação escolar}

O desenho da empiria deste estudo revela que existem singularidades nos meios de produzir a vida do trabalhador do campo e no acesso à educação escolar, no sentido de que essa realidade apresenta mais necessidades, não para abandonar a totalidade, mas no sentido de haver mais ausência nas formas de produzir a vida e de distribuição dos conhecimentos e fruição da vida, devido às precárias condições objetivas. Não obstante, para o projeto do capital, não há diferenciação nos fundamentos da produção material da vida e de uma educação do trabalhador do campo e da cidade quando se trata de educação para pobres. Contudo, os meios de produção da vida dos trabalhadores familiares no Terceiro Anel, na RMC, revelam que não basta ter acesso à terra se não há condições de produzir, de distribuir e de consumir os feitos do seu trabalho e se o acesso ao conhecimento é privado.

A educação que chega aos trabalhadores familiares é apenas para garantir a sobrevivência e não para atender as suas necessidades humanas. Nesse sentido, ocorre um processo de redução da subjetividade do trabalhador, constituindo o "[...] estranhamento de todas as forças humanas essenciais (sensações, paixões, pensamentos), a sua degradação a um nível tacanho de miséria e penúria, a mera orientação para possuir o que é útil a existência física" (DELLA FONTE, 2014, p. 390). Nesse processo, compreende-se que o modo de produzir a vida no campo faz parte da totalidade de determinações sociais, mas a apropriação da educação escolar dá-se pela ausência da escola pública de qualidade e pela exclusão dos conhecimentos da ciência, da filosofia e da arte.

Nesse quadro, o desafio que se coloca à apropriação da educação escolar no Terceiro Anel, na RMC, é a defesa e a garantia de escola de qualidade em seus vários níveis e em um diálogo com os movimentos sociais do campo. De acordo com os dados apresentados sobre as condições de trabalho dos trabalhadores do campo, a maioria dos municípios da RMC possui um índice baixo de conclusão do Ensino Médio com 17 anos. Aliado a isso, os dados sobre a escolaridade da maioria dos trabalhadores familiares e assalariados no campo a partir de 14 anos é o Ensino Fundamental Incompleto. Esses dados mencionados conectam-se ao debate histórico da ampliação da educação escolar no campo (VENDRAMINI; SAPELLI, 2014) e, ao mesmo tempo, com o fechamento e a paralisação das escolas localizadas no campo na RMC (INEP, 2015).

Outro desafio que se coloca aos trabalhadores do campo diz respeito ao debate sobre a ontologia do trabalho e a educação de forma que isso se expresse por meio da democratização do conhecimento historicamente acumulado e sistematizado e da organização do trabalho didático sobre outras bases, ou seja, incorporar como os homens apropriam a vida humana, a produção, a distribuição, a troca e o consumo (MARCOCCIA, 2015). Nesse sentido, o desafio histórico para a apropriação da educação escolar dos trabalhadores familiares no Terceiro Anel, na RMC, está ligado à relação entre os meios de produção da vida e a educação, que tem como finalidade a luta por transformações nas relações de produção e a defesa de uma escola pública de qualidade para todos.

Práxis Educativa, Ponta Grossa, v. 12, n. 2, p. 595-616, maio/ago. 2017 Disponível em: <http://www.revistas2.uepg.br/index.php/praxiseducativa $>$ 
Trata-se de incorporar com radicalidade posicionamentos de transformação nas relações de produção, principalmente frente à precarização dos trabalhadores do campo. Isso implica ter o trabalho como centralidade das ações nos diversos espaços formativos, dentre eles, a escola pública, que precisa romper com o pragmatismo, a fragmentação entre o trabalho manual e intelectual e seu sistema de internalização que naturaliza as relações entre capital, trabalho e educação. O desafio fundamental que se coloca à educação nesse contexto é conectar a produção da vida às necessidades humanas, não sendo possível produzir a existência humana com dignidade sem apropriar conhecimento.

\section{Considerações finais}

A abordagem teórica eleita possibilita apontar, à guisa de considerações finais, que o trabalho no campo se caracteriza pelo predomínio do trabalho parcializado, presente no trabalho assalariado que se constitui em funções cada vez mais simplificadas e de baixa qualificação. Por sua vez, os meios de produção da vida do trabalhador familiar seguem a mesma tendência do setor de emprego formal, ou seja, há um processo de homogeneização das relações de trabalho no campo e na cidade.

Em suma, os trabalhadores do Terceiro Anel, na RMC, estão sob precárias condições de trabalho, em virtude de como os meios de produção da vida e a educação foram distribuídos e apropriados nas relações sociais. Os setores de emprego no Terceiro Anel revelam processos cada vez mais simplificados e controles rígidos para trabalhadores com baixa qualificação. Isso contribui para a alta rotatividade e a flexibilização do emprego. $O$ trabalhador familiar, nesse contexto, perdeu a posse dos meios de produção de existência e foi sendo capacitado para atender o regime de acumulação flexível, cuja finalidade é incorporá-lo à força de trabalho assalariada.

Há perda da autonomia do trabalhador familiar, o qual passa a se submeter ao "[...] padrão hegemônico de desenvolvimento que [impõe] a forma de trabalho, o tipo de produção, o uso de insumos, de tecnologias [...] que tem como significado ser mais competitivo por meio do aumento da produção via trabalho assalariado" (SOUSA, 2011, p. 64).

A classe empresária que está no Terceiro Anel, na RMC, possui instrumentos altamente desenvolvidos que rebaixam e eliminam o trabalhador, apropriando o excedente do seu trabalho. Mediante isso é possível perceber que há uma relação contraditória do capital com os trabalhadores familiares. Ao mesmo tempo que o capital, para se expandir, expulsa esses trabalhadores, por outro lado, para se apropriar da renda da terra, da riqueza, precisa da força de trabalho assalariada. Nesse sentido, não pode expropriar completamente essa força de trabalho. Reconhecendo isso, o capital nem sempre expropria a propriedade, mas "[...] expropria o excedente que se forma pela posse [...] da terra" (OLIVEIRA, 2013, p. 43).

Nesse sentido, o trabalhador tem acesso apenas ao necessário para garantir a sua sobrevivência e se manter como força de trabalho assalariada, ou seja, empregos menos qualificados que requerem baixa escolaridade, produzindo alta rotatividade para que se insiram em trabalhos de baixa remuneração.

Nesse cenário, o capital acentua a divisão social do trabalho para que os trabalhadores não se apropriem da unidade de sua atividade. Ao fragmentar o trabalho, desencadeia processos de consenso que ajudam a concretizar a exploração do homem pelo homem e a expropriação do trabalhador dos meios de produzir a sua existência, mantendo essas relações inalteradas. Contraditoriamente, essas mesmas relações que formam um trabalho estranhado, que, conforme 
Antunes (2008), se trata da existência de barreiras sociais que se opõem ao desenvolvimento da personalidade humana, deixam brechas que possibilitam que essas relações sejam desveladas na sua essência. Ao apropriar esse movimento real, em uma perspectiva crítica, criam-se outras possibilidades para a superação dessa forma desumanizadora produzida pelo capital.

Por sua vez, a educação tem um papel fundamental nesse processo, que é se posicionar com radicalidade sobre a produção da existência dos trabalhadores do campo. Ao mesmo tempo, pensar alternativas contra-hegemônicas à ordem existente, sem perder de vista a defesa e a garantia da escola pública de qualidade para todos, em que haja mediação dos conhecimentos sistematizados com os meios de produzir a vida, em um diálogo com os movimentos sociais de trabalhadores do campo, cuja finalidade seja o trabalho de produtores associados.

Embora, desde o final da década de 1990, os movimentos sociais de trabalhadores do campo tenham conquistado direitos acerca da educação dos trabalhadores do campo, fruto da luta social, o desenho dessa empiria revela que a apropriação da educação escolar desses trabalhadores ainda é expressivamente desigual e fragmentada, o que impõe a emergência de discutir a apropriação dos conhecimentos dos trabalhadores do campo articulados aos meios de produção da vida. E, a partir disso, apontar os desafios educacionais que se colocam à escola pública de qualidade para todos.

Cumprem-se, no Terceiro Anel, na RMC, entre os trabalhadores do campo, as tendências enunciadas na Introdução deste estudo, a saber: subcontratação, curta duração, terceirização dos contratos de trabalho, fragmentação/parcialização, trabalho desqualificado e baixa escolaridade. Isso não se dá sem profundas alterações na subjetividade dos trabalhadores e nas relações com o capital. Há, entretanto, desafios a serem trabalhados que passam, sem dúvida, pela escola pública crítica.

\section{Referências}

ABRAMOVAY, R. Paradigmas do capitalismo agrário em questão. São Paulo: Edusp, 2012.

ANTUNES, R. L. C. Adeus ao trabalho? Ensaio sobre as metamorfoses e a centralidade do mundo do trabalho. São Paulo: Cortez, 2008.

ANTUNES, R. L. C. O continente do labor. São Paulo: Boitempo, 2011.

BRAGA, R. A política do precariado: do populismo à hegemonia lulista. São Paulo: Boitempo, 2016.

BRAGA, R. Para onde vai o precariado brasileiro? Sindicalismo e hegemonia no Brasil contemporâneo. Perseu, São Paulo, n. 10, ano 7, p. 141-155, 2013.

BRAVERMAN, H. Trabalho e capital monopolista. Rio de Janeiro: Zahar, 1980.

DELLA FONTE, S. S. A formação humana em debate. Educação \& Sociedade, Campinas, v. 35, n. 127, p. 379-395, abr./jun. 2014. DOI: 10.1590/s0101-73302014000200003

DIEESE. Departamento Intersindical de Estatística e Estudos Socioeconômicos. Os números da rotatividade no Brasil: um olhar sobre os dados da RAIS 2002-2013. São Paulo: Dieese, 2014.

Práxis Educativa, Ponta Grossa, v. 12, n. 2, p. 595-616, maio/ago. 2017 Disponível em: <http://www.revistas2.uepg.br/index.php/praxiseducativa> 
FERNANDES, B. M. Conflitualidade e desenvolvimento territorial. In: BUAINAIN, A. M. et al. (Coords.). Luta pela terra, reforma agrária e gestão de conflitos no Brasil. Campinas: Unicamp, 2008. p. 173-230.

FERNANDES, B. M. A Reforma Agrária que o governo Lula fez e a que pode ser feita. In: SADER, E. (Org.). 10 anos de governos pós-neoliberais no Brasil: Lula e Dilma. São Paulo: Boitempo, 2013. p. 191-205.

FETAEP. Federação dos Trabalhadores na Agricultura do Estado do Paraná. Principal. Curitiba, 2013. Disponível em: <https://voluntariadobb.v2v.net/aggregators/91>. Acesso em: 10 jul. 2014.

FRIGOTTO, G. Desafios históricos e atuais da educação dos trabalhadores. In: PALUDO, C. (Org.). Campo e cidade em busca de caminhos comuns. Pelotas: UFPel, 2014. p. 43-64.

GUERRA, A.; POCHMANN, M.; SILVA, R. A. Atlas da exclusão social no Brasil: dez anos depois, v. 1. São Paulo: Cortez, 2014.

IBGE. Instituto Brasileiro de Geografia e Estatística. Censo Agropecuário: agricultura familiar. Brasília, DF: IBGE, 2006. Disponível em: <www.ibge.gov.br/censoagropecuario2006>. Acesso em: 10 jul. 2013.

IBGE. Instituto Brasileiro de Geografia e Estatística. Pesquisa Nacional por Amostra de Domicílios 2008 - PNAD. Rio de Janeiro: IBGE, 2008. v. 29.

IBGE. Instituto Brasileiro de Geografia e Estatística. Censo Demográfico de 2010. Brasília, DF: IBGE, 2010. Disponível em: <www.ibge.gov.br/censo2010>. Acesso em: 1 ago. 2011.

INEP. Instituto Nacional de Estudos e Pesquisas Educacionais Anísio Teixeira. Data Escola Brasil. Brasília, DF: INEP, 2015.20 Disponível em: <http://www.dataescolabrasil.inep.gov.br/dataEscolaBrasil/>. Acesso em: 1 jul. 2015.

KUENZER, A. Z. Trabalho e escola: aprendizagem flexibilizada. In: REUNIÃO CIENTÍFICA REGIONAL DA ANPED, 11., 2016, Curitiba, PR. Anais... Curitiba: ANPED SUL, 2016.

LUSTOSA, M. G. O. Reforma Agrária à brasileira: política social e pobreza. São Paulo: Cortez, 2012.

MARCOCCIA, P. C. de P. Degradação do trabalho no campo na região metropolitana de Curitiba: desafios à educação. 2015. 213 f. Tese (Doutorado em Educação) - Universidade Tuiuti do Paraná, Curitiba, 2015.

MARX, K. Contribuição à crítica da economia política. São Paulo: Expressão Popular, 2008.

MARX, K. O Capital. Crítica da economia política. Rio de Janeiro: Civilização Brasileira, 2009.

MARX, K. O Capital. Crítica da economia política. São Paulo: Boitempo, 2013.

MOLINA, M. C.; MONTENEGRO, J. L. de A.; OLIVEIRA, L. L. N. de A. Das desigualdades aos direitos: a exigência de políticas afirmativas para a promoção da equidade educacional no 
campo. Raízes, Campina Grande, v. 28, n. 1 e 2, p. 174-190, jan./dez. 2009; v. 29, n. 1, jan./jun. 2010 .

NEAD. Núcleo de Estudos Agrários e Desenvolvimento Rural. Estatísticas do meio rural. São Paulo: DIEESE, NEAD, 2008.

OLIVEIRA, F. de. Crítica à razão dualista: o ornitorrinco. São Paulo: Boitempo, 2013.

SENAR. Serviço Nacional de Aprendizagem Rural. Apresentação. 2014. Disponível em: <http://www.senar.org.br/sobre-senar/apresentacao>. Acesso em: 22 dez. 2014.

SOUSA, R. A. D. Trabalho e trabalhadores no campo: desvendando a realidade no vale do São Francisco. In: CONCEIÇÃO, A. L. (Org.). Trabalho e trabalhadores: as novas configurações espaciais da reestruturação produtiva no espaço rural. São Cristóvão: UFS, 2011. p. 63-197.

VENDRAMINI, C. R.; SAPELLI, M. L. S. Educação do Campo: uma particularidade na universalidade. In: MELO, A.; HIDALGO, Â. M.; SAPELLI, M. L. S. (Orgs.). Terra e educação: contexto e experiências em Educação do Campo. Guarapuava: Unicentro, 2014. p. 83-115.

ZANCHET, M. S. Características das ocupações na agropecuária paranaense. IPARDES Primeira Versão, Curitiba, n. 7, p. 3-35, 2008.

ZANCHET, M. S. Tendências e desafios do emprego rural no Paraná. Revista Paranaense de Desenvolvimento, Curitiba, n. 118, p. 159-173, jan./jun. 2010. 